\title{
ANALISA DIMENSI DAN TULANGAN PELAT LANTAI PADA RUKO R1- GABUNG NO. 18, 20, 26, 28, 30, 32 DAN 36 BANGUNAN CITRALAND BAGYA CITY MEDAN
}

\author{
Widya Desni Sitorus ${ }^{1}$, Sutrisno ${ }^{2}$ \\ ${ }^{1}$ Alumni Program Studi D3 Teknik Sipil, Fakultas Teknik UNIMED \\ ${ }^{2}$ Dosen Pengajar Jurusan Pendidikan Teknik Bangunan, Fakultas Teknik UNIMED \\ (sutrisno_unimed@yahoo.com)
}

\begin{abstract}
ABSTRAK
Artikel ini bertujuan untuk mengetahui besaran dimensi dan tulangan pelat lantai pada suatu konstruksi bangunan. Pelat lantai adalah komponen struktur bangunan yang memiliki dimensi tertentu untuk menyalurkan beban mati dan beban hidup di atasnya untuk disalurkan kepada penopangnya. Dalam merencanakan pelat lantai sebuah bangunan diperlukan data- data beban yang akan dipikul oleh struktur tersebut, sehingga struktur yang direncanakan mampu memikul beban dan gaya- gaya yang bekerja. Dengan perencanaan yang matang diharapkan akan dihasilkan dimensi dan tulangan pelat lantai yang ekonomis dan aman dimana terhindar dari lendutan dan retak.

Bangunan yang ditinjau adalah Ruko R1- Gabung No. 18, 20, 26, 28, 30, 32 dan 36 Citraland Bagya City Medan. Bangunan ini terdiri atas tujuh ruko gandeng berlantai empat dengan ketinggian mencapai 15,17 m yang berlokasi di Jln. Boulevard Barat Raya Kav 01 Medan. Perencanaan dimensi dan tulangan pada bangunan ruko ini meliputi pelat satu arah dan pelat dua arah dengan variasi ukuran yang berbeda- beda. Analisis dilakukan dengan 'metode amplop' sesuai dengan buku Kusuma Gideon (Dasar- Dasar Perencanaan Beton Bertulang).

Hasil analisa dimensi dan tulangan pada bangunan ruko ini adalah: a) dimensi/ tebal pelat pada pelat atap $100 \mathrm{~mm}$, sedangkan pada pelat lantai 4, 3 dan 2 adalah $120 \mathrm{~mm}$; b) tulangan yang digunakan pada pelat lantai ini adalah besi polos $\emptyset 8$ dengan jarak bervariasi pada setiap momen yang dianalisis yang terdapat pada tabel hasil analisis dan gambar penulangan pelat lantai.
\end{abstract}

Kata Kunci : dimensi, pelat lantai, tulangan

\begin{abstract}
This article aims to determine the magnitude of the dimensions and reinforcement plates on the floor of a building construction. Floor plate is a component structure that has a particular dimension to channel the dead load and live load on it for distribution to the jib. In planning a building floor plate is required data- the data load is borne by such structures, so that the planned structure is able to bear the burden and the forces that work. With careful planning is expected to be generated dimensions and floor slab reinforcement economical and safe where avoid deflections and crack.

The building that looked at is office R1-Merge No. 18, 20, 26, 28, 30, 32 and 36 Citraland Bagya City Medan. The building consists of seven four-storey shophouses trailer with a height of up to $15.17 \mathrm{~m}$, located at Jln. Boulevard Barat Raya Kav 01 Medan. Planning dimensions and reinforcement in the shop building includes plate one-way and two-way plate with a variety of different sizes. The analysis was performed with the 'envelope method' according to the book Gideon Kusuma (Reinforced Concrete foundations Planning).

Results of analysis of the dimensions and reinforcement in the shop building are: a) dimensions / plate thickness on the roof plate of $100 \mathrm{~mm}$, while on the floor plate 4, 3 and 2 is $120 \mathrm{~mm}$; b) reinforcement used in the floor plate is a plain iron $\emptyset 8$ with varying distances at every moment that analyzed contained in the analysis result table and floor slab reinforcement drawings.
\end{abstract}

Keywords: dimensions, floor slabs, reinforcement 


\section{Pendahuluan}

Di dalam perencanaan desain struktur konstruksi bangunan, ditemukan dua bagian utama dari bangunan, yaitu bagian struktur dan nonstruktur. Pelat lantai merupakan bagian struktur yang sangat penting, dimana ikut memikul beban yang bekerja pada bangunan. Pelat adalah elemen horizontal struktur yang mendukung beban mati maupun beban hidup dan menyalurkannya ke rangka vertikal dari sistem struktur.

Masalah utama yang dihadapi dalam perencanaan pelat lantai adalah lendutan. Masalah ini dapat disebabkan antara lain karena kesalahan pada perencanaan dimensi dan tulangan sehingga tulangan yang dipasang tidak cukup menahan beban yang bekerja. Selain itu, penyebab lainnya adalah penggunaan bahan/ material yang kurang baik pada saat pemasangan tulangan, sehingga dapat mengurangi kekuatan beton bertulang. Pada dasarnya perencanaan yang baik adalah apakah pelat lantai cukup kuat menahan beban atau tidak. Karena di dalam perencanaan tersebut akan dihasilkan besaran dimensi dan tulangan yang seharusnya digunakan. Bila perhitungan keliru atau mengalami kesalahan dapat menyebabkan perbedaan dimensi dan penulangan dari hasil perhitungan dengan dimensi dan tulangan yang seharusnya dipasangan di lapangan.

Untuk itu penulis tertarik mengambil judul: Analisa Dimensi dan Tulangan Pelat Lantai pada Ruko R1- Gabung No. 18, 20, 26, 28, 30, 32 dan 36 Bangunan Citraland Bagya City Medan

\section{Kajian Teori}

Pelat lantai merupakan sebuah bidang datar yang lebar, biasanya mempunyai arah horizontal dengan permukaan atas dan bawahnya sejajar. Pelat lantai biasanya ditumpu oleh gelagar atau balok beton bertulang, oleh dinding pasangan batu atau beton bertulang, oleh batang- batang struktur baja secara langsung oleh kolom, atau bertumpu secara menerus ke tanah.

Fungsi pelat lantai antara lain: memisahkan bagian- bagian dari lantai, memindahkan beban pada dinding, menambah kekakuan sebuah bangunan, mencegah perambatan gema suara, isolasi terhadap pertukaran temperatur/ suhu.

Menurut Daniel L. Schodek (Struktur, hal 338): bahwa beban pelat dipikul pada kedua arah oleh empat balok pendukung sekeliling panel, dengan demikian pelat menjadi suatu pelat yang melentur pada kedua arah.

Secara analisis, apabila perbandingan antara bentang panjang dan bentang lebar pelat tidak lebih dari dua, maka digunakan penulangan dua arah.Apabila nilai perbandingan antara panjang dan lebar pelat lebih dari dua, maka digunakan penulangan satu arah (Dipohusodo, 1994).

Dalam merencanakan struktur bangunan bertingkat, digunakan struktur yang mampu mendukung berat sendiri, beban angin, beban hidup maupun beban khusus yang bekerja pada struktur bangunan tersebut. Beban- beban yang bekerja pada struktur dihitung menurut SNI 03-1727-1989.Adapun langkah- langkah perhitungan pelat lantai berdasarkan SKSNI T15-1991-03:

1) Menentukan syarat- syarat batas dan bentangnya ( $l x$ dan $l y)$

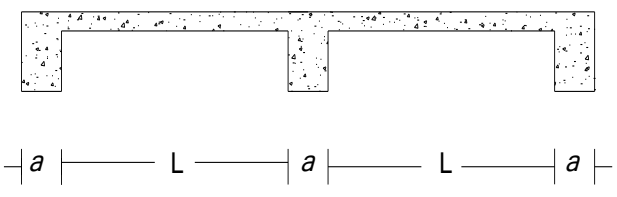

2) Menentukan tebal pelat $(h)$

$$
\begin{aligned}
& h \geq \frac{\ln \left(0,8+\frac{f y}{1500}\right.}{36+5 \beta\left[\alpha_{m}-0,12\left(1+\frac{1}{\beta}\right)\right]} \\
& h_{\text {min }} \geq \frac{\ln \left(0,8+\frac{f y}{1500}\right.}{36+9 \beta} \\
& h_{\text {maks }} \leq \frac{\ln \left(0,8+\frac{f y}{1500}\right.}{36}
\end{aligned}
$$

3) Menentukan beban- beban yang bekerja, meliputi beban idup dan beban mati serta kombinasinya.

$$
\mathrm{W}_{\mathrm{U}}=1,2 \mathrm{~W}_{\mathrm{D}}+1,6 \mathrm{~W}_{\mathrm{L}}
$$

4) Menentukan momen yang bekerja $(\mathrm{Mu})$, dihitung dengan skema pada 'metode amplop', meliputi momen lapangan dan tumpuan (Mlx, Mly, Mtx, Mty, Mtix dan Mtiy)

5) Menghitung rasio tulangan

$$
\begin{aligned}
\rho_{\text {min }} & =\frac{1,4}{f y} \\
\rho_{\text {maks }} & =0,75\left(0,85 \frac{f^{\prime} c}{f y} \times \frac{600}{600+f y}\right)
\end{aligned}
$$


Rasio tulangan perlu ( $\left.\rho_{\text {analisa }}\right)$ :

$\frac{M u}{b d^{2}}=\phi \cdot \rho \cdot f y\left[1-0,588 \rho \frac{f y}{f^{\prime} c}\right]$

Jika $\rho$ anl $<\rho \min \Rightarrow \rho \min$

Jika $\rho$ anl $>\rho$ maks $\Rightarrow \rho$ maks
6) Perhitungan penulangan

As perlu $=\rho_{\text {analisa }} \cdot \mathrm{b} \cdot \mathrm{d}$

As $\emptyset$ tulangan $=1 / 4 \pi d^{2}$

$n$ (jumlah tulangan $)=\frac{\text { As perlu }}{\text { As tulangan }}$

$S($ jarak $)=\frac{1000}{\mathrm{n}}$

\section{Hasil dan Pembahasan}

Data Struktur:

Tinggi bangunan $=4$ lantai $(15,17 \mathrm{~m})$

Fungsi bangunan $=$ Rumah toko

Mutu beton $f^{\prime} c=25 \mathrm{MPa}$

Struktur bangunan $=$ Beton bertulang

Mutu baja $f^{\prime} y=240 \mathrm{MPa}$

Data geometri bangunan ruko yang dianalisa adalah sebagai berikut:

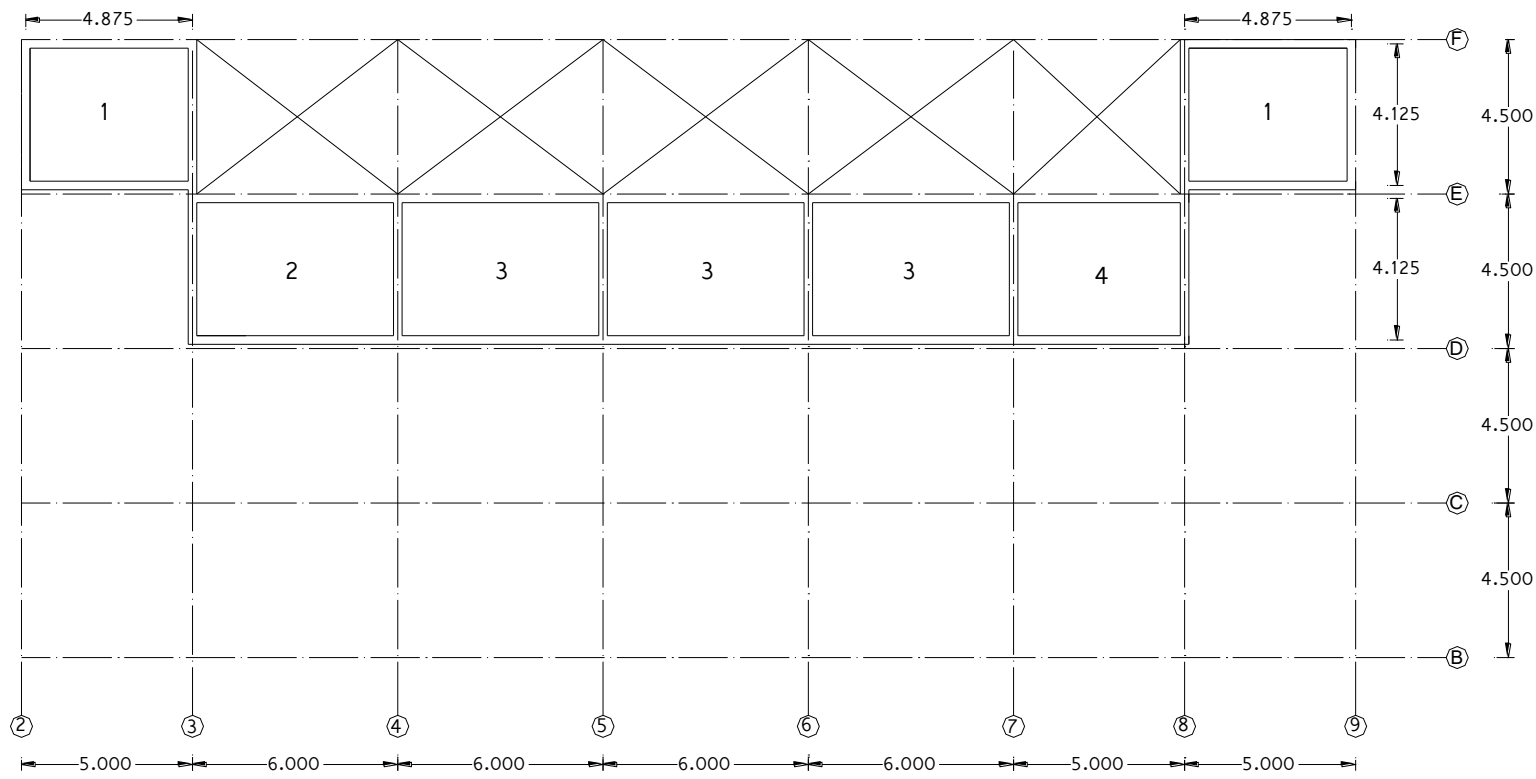

Gambar 1. Denah Dak Atap

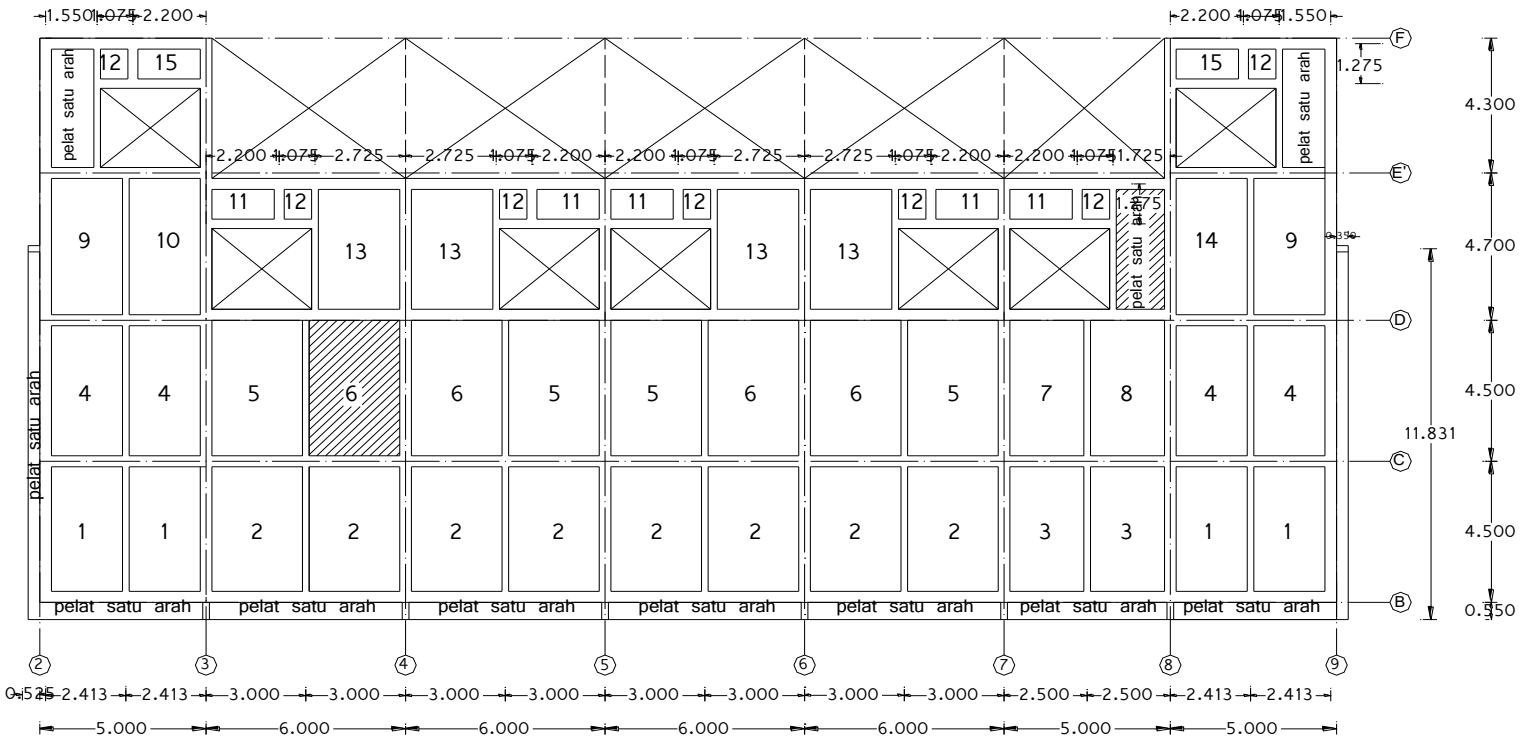

Gambar 2. Denah Lantai Empat 


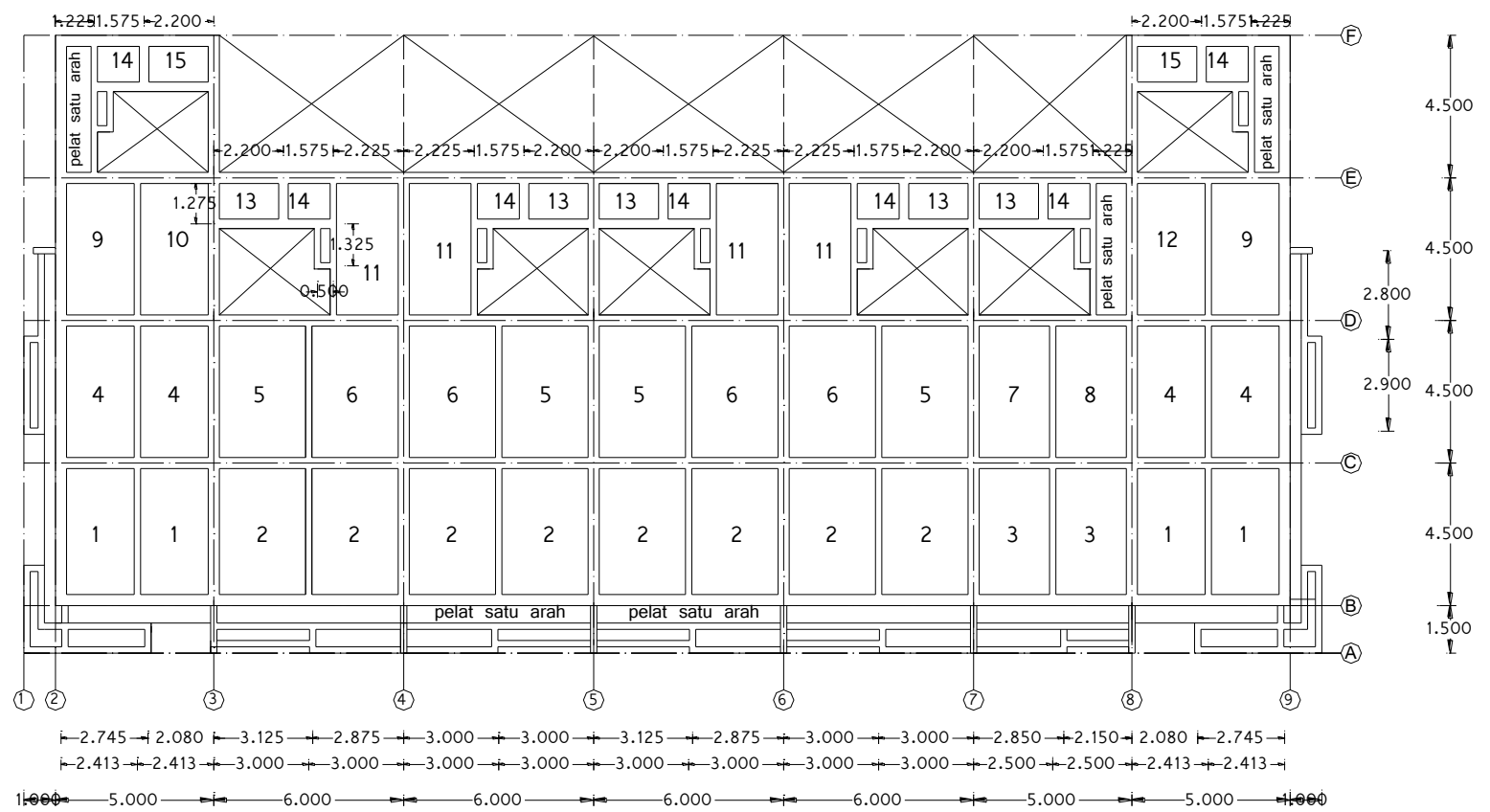

Gambar 3. Denah Lantai Dua

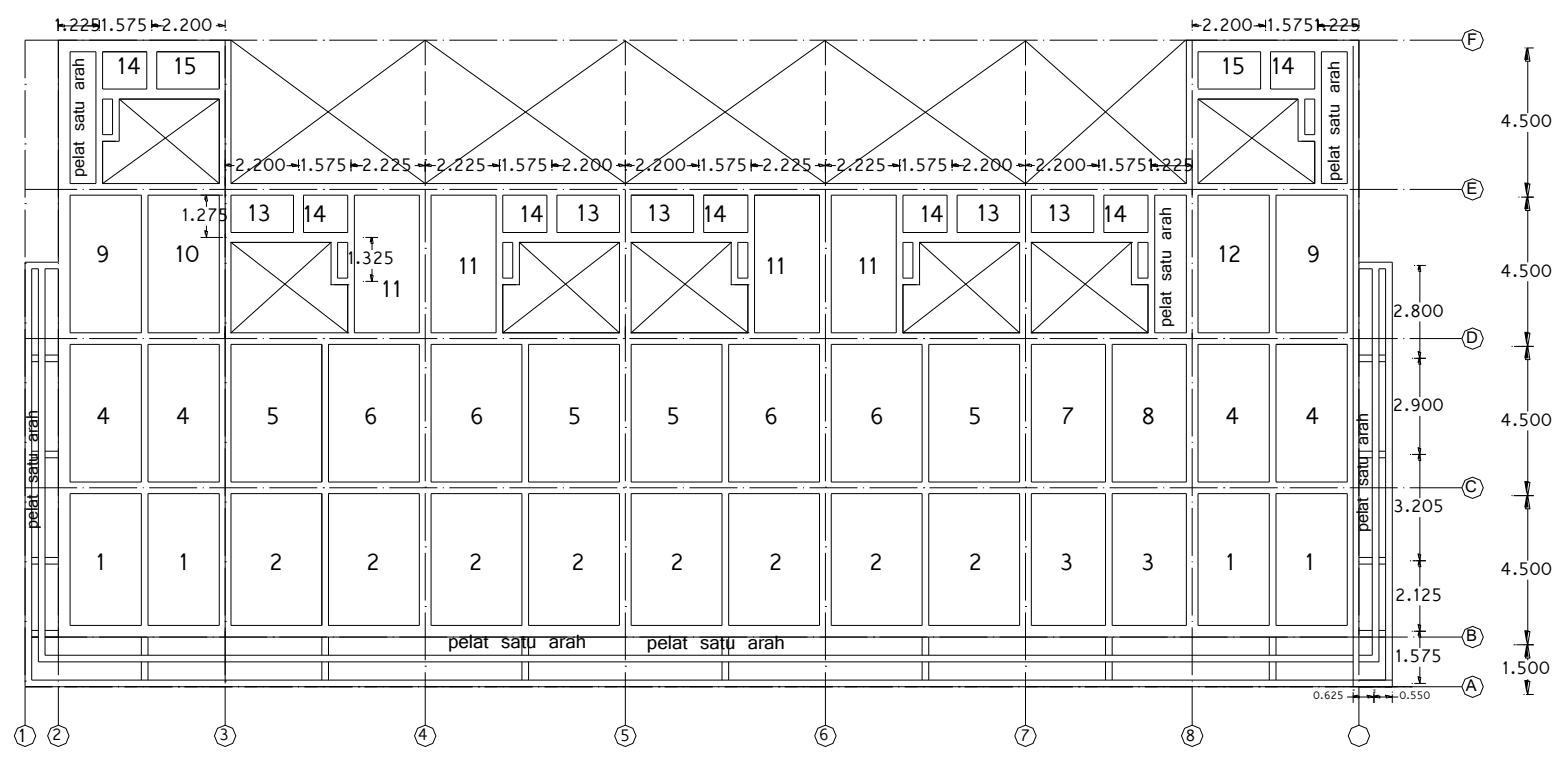

$+2.413 \rightarrow+-2.413 \rightarrow+-3.000 \rightarrow+-3.000 \rightarrow+3.000 \rightarrow+-3.000 \rightarrow+3.000 \rightarrow+-3.000 \rightarrow+-3.000 \rightarrow+-3.000 \rightarrow+-2.500 \rightarrow+-2.500 \rightarrow+-2.413 \rightarrow+-2.413 \rightarrow+4$

Gambar 4. Denah Lantai Dua

Perhitungan pelat dua arah:

1) Syarat Batas

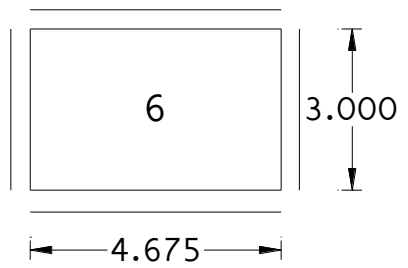

$\mathrm{Ly}=4,675 \mathrm{~m}=4675 \mathrm{~mm}$ $\mathrm{Lx}=3 \mathrm{~m}=3000 \mathrm{~mm}$

$$
l y / l x=\frac{4675}{3000}=1,56
$$

2) $h$ minimum ( $h$ min) dan maksimum hmin $=\frac{l}{28}=\frac{4675}{28}=166,96 \mathrm{~mm}$ di ambil $h$ balok $=350 \mathrm{~mm}$ $\mathrm{bw}=1 / 2 \times \mathrm{h}$ balok $=175 \mathrm{~mm}$ $\beta=\frac{l y-b w}{l x-b w}=\frac{4675-175}{3000-175}=1,59$ 
$\ln =1 \mathrm{y}-\mathrm{bw}=4500 \mathrm{~mm}$

$h \min \geq \frac{0.8+240 / 1500}{36+9(1,59)} \times 4500$

$h \min \geq 85,87 \mathrm{~mm}$

$h \max \leq \frac{0.8+\frac{240}{1500}}{36} \times 4500$

$h \max \leq 120 \mathrm{~mm}$

Karena $h \max =h$ minSNI, maka asumsi

tebal pelat yang direncanakan:

$\Longrightarrow$ Pelat lantai $=120 \mathrm{~mm}$

$\Rightarrow$ Pelat dak atap $=100 \mathrm{~mm}$
3) Beban yang bekerja

a) Lantai atap

Beban mati $=300 \mathrm{~kg} / \mathrm{m}^{2}$

- Meliputi berat sendiri pelat, berat lapisan kedap air dan berat plafond dan penggantung.

Beban hidup $=130 \mathrm{~kg} / \mathrm{m}^{2}$

- Meliputi beban atap dan air hujan

Beban mati lantai 2,3,4 $=429 \mathrm{~kg} / \mathrm{m}^{2}$

- Meliputi berat sendiri pelat, finising, berat keramik dan berat plafond.

Beban hidup lantai $2,3,4=250 \mathrm{~kg} / \mathrm{m}^{2}$

4) Momen- momen yang bekerja dihitung sesuai skema pelat pada 'metode amplop'. Lalu hasil peritungan ditabelkan sebagai berikut:

Tabel 1. Analisis Tulangan Pelat Atap Kasus Pelat Dua Arah

\begin{tabular}{|c|c|c|c|c|c|c|c|c|}
\hline $\mathrm{m}$ & Koef & $\mathrm{Mu}$ & $\mathrm{Mu} / \mathrm{bd}^{2}$ & $\rho$ anl & $\rho \min$ & $\begin{array}{c}\text { As } \\
\left(\mathrm{mm}^{2}\right)\end{array}$ & $\begin{array}{c}\text { Tulangan hasil } \\
\text { perhitungan }\end{array}$ & $\begin{array}{l}\text { Tulangan } \\
\text { terpasang }\end{array}$ \\
\hline \multicolumn{9}{|c|}{ Hasil analisis tulangan akhir pada kasus 1 skema I } \\
\hline $\mathrm{mlx}$ & 0.0527 & 0.5093 & 88.18 & 0.0044 & 0.0025 & 336.95 & $\varnothing 8-149.10$ & $\varnothing 8-125$ \\
\hline mly & 0.0356 & 0.3441 & 74.41 & 0.0037 & 0.0025 & 253.36 & $\varnothing 8-198.29$ & $\varnothing 8-125$ \\
\hline mtix & 0.0264 & 0.2547 & 44.09 & 0.0022 & 0.0025 & 190 & $\varnothing 8-264.42$ & $\varnothing 8-250$ \\
\hline mtiy & 0.0178 & 0.1720 & 37.20 & 0.0018 & 0.0025 & 170 & $\varnothing 8-295.53$ & $\varnothing 8-250$ \\
\hline \multicolumn{9}{|c|}{ Hasil analisis tulangan akhir pada kasus 2 skema Va } \\
\hline $\mathrm{mlx}$ & 0.0613 & 0.5925 & 102.57 & 0.0052 & 0.0025 & 399.27 & $\varnothing 8-127.63$ & $\varnothing 8-150$ \\
\hline mly & 0.0330 & 0.3189 & 68.98 & 0.0034 & 0.0025 & 246.28 & $\varnothing 8-214.26$ & $\varnothing 8-150$ \\
\hline mty & 0.1088 & 1.0515 & 227.41 & 0.0120 & 0.0025 & 842.62 & $\varnothing 8-61.80$ & $\varnothing 8$ - 75 \\
\hline mtix & 0.0306 & 0.2962 & 51.29 & 0.0026 & 0.0025 & 196.58 & Ø8 - 255.56 & $\varnothing 8-225$ \\
\hline mtiy & 0.0165 & 0.1595 & 34.49 & 0.0017 & 0.0025 & 170.00 & $\varnothing 8-295.53$ & $\varnothing 8-225$ \\
\hline \multicolumn{9}{|c|}{ Hasil analisis tulangan akhir pada kasus 3 skema IVa } \\
\hline $\mathrm{mlx}$ & 0.0525 & 0.5074 & 87.85 & 0.0044 & 0.0025 & 335.64 & Ø8 - 149.68 & $\varnothing 8-150$ \\
\hline mly & 0.0313 & 0.3025 & 65.42 & 0.0033 & 0.0025 & 222.17 & $\varnothing 8-226.13$ & $\varnothing 8-150$ \\
\hline mty & 0.0990 & 0.9568 & 206.93 & 0.0108 & 0.0025 & 734.54 & $\varnothing 8-68.40$ & $\varnothing 8-75$ \\
\hline mtix & 0.0262 & 0.2537 & 43.92 & 0.0022 & 0.0025 & 190 & $\varnothing 8-264.42$ & $\varnothing 8-250$ \\
\hline \multicolumn{9}{|c|}{ Hasil analisis tulangan akhir pada kasus 4 skema Va } \\
\hline $\mathrm{mlx}$ & 0.0450 & 0.4509 & 78.06 & 0.0039 & 0.0025 & 297.38 & $\varnothing 8-168.94$ & $\varnothing 8-150$ \\
\hline mly & 0.0379 & 0.3707 & 80.17 & 0.0040 & 0.0025 & 273.45 & Ø8 - 183.72 & $\varnothing 8-150$ \\
\hline mty & 0.102 & 1.0220 & 221.02 & 0.0116 & 0.0025 & 788.32 & $\varnothing 8-63.73$ & $\varnothing 8-75$ \\
\hline mtix & 0.0225 & 0.2254 & 39.03 & 0.0019 & 0.0025 & 190 & $\varnothing 8-264.42$ & $\varnothing 8-250$ \\
\hline mtiy & 0.0185 & 0.1854 & 40.09 & 0.0020 & 0.0025 & 170.00 & Ø8 - 295.53 & $\varnothing 8-250$ \\
\hline
\end{tabular}

Tabel 2. Analisis Tulangan Pelat Lantai 4 Kasus Pelat Dua Arah

\begin{tabular}{|c|c|c|c|c|c|c|c|c|}
\hline $\mathrm{m}$ & koef & $\mathrm{Mu}$ & $\mathrm{Mu} / \mathrm{bd}^{2}$ & $\rho$ anl & $\rho \min$ & $\begin{array}{c}\text { As } \\
\left(\mathrm{mm}^{2}\right)\end{array}$ & $\begin{array}{c}\text { Tulangan hasil } \\
\text { perhitungan }\end{array}$ & $\begin{array}{l}\text { Tulangan } \\
\text { terpasang }\end{array}$ \\
\hline
\end{tabular}

Hasil analisis tulangan akhir pada kasus 1, 2, 3, 4, 6, 8, 9 skema II

$\begin{array}{lllllllll}\mathrm{mlx} & 0.053 & 0.2823 & 30.63 & 0.0015 & 0.0025 & 240 & \varnothing 8-209.33 & \varnothing 8-200\end{array}$




\begin{tabular}{ccccccccc}
\hline mly & 0.015 & 0.0799 & 10.32 & 0.0005 & 0.0025 & 220 & $\varnothing 8-228.36$ & $\varnothing 8-200$ \\
mtx & 0.081 & 0.4314 & 46.81 & 0.0023 & 0.0025 & 240 & $\varnothing 8-209.33$ & $\varnothing 8-100$ \\
mty & 0.054 & 0.2876 & 37.14 & 0.0018 & 0.0025 & 220 & $\varnothing 8-228.36$ & $\varnothing 8-100$ \\
\hline \multicolumn{7}{c}{ Hasil analisis tulangan akhir pada kasus $5,7,14,15$ skema VIIb } \\
\hline mlx & 0.0490 & 0.2610 & 28.32 & 0.0014 & 0.0025 & 240 & $\varnothing 8-209.33$ & $\varnothing 8-200$ \\
mly & 0.0182 & 0.0969 & 12.52 & 0.0006 & 0.0025 & 220 & $\varnothing 8-228.36$ & $\varnothing 8-200$ \\
mtx & 0.0792 & 0.4219 & 45.77 & 0.0023 & 0.0025 & 240 & $\varnothing 8-209.33$ & $\varnothing 8-100$ \\
mty & 0.0542 & 0.2887 & 37.28 & 0.0018 & 0.0025 & 220 & $\varnothing 8-228.36$ & $\varnothing 8-100$ \\
mtiy & 0.0091 & 0.0485 & 6.26 & 0.0003 & 0.0025 & 220 & $\varnothing 8-228.36$ & $\varnothing 8-200$ \\
\hline \multicolumn{7}{c}{ Hasil analisis tulangan akhir pada kasus 10,13 skema III } & \\
\hline mlx & 0.0708 & 0.3771 & 40.92 & 0.0020 & 0.0025 & 240 & $\varnothing 8-209.33$ & $\varnothing 8-200$ \\
mly & 0.0193 & 0.1028 & 13.27 & 0.0007 & 0.0025 & 220 & $\varnothing 8-228.36$ & $\varnothing 8-200$ \\
mtx & 0.116 & 0.6179 & 67.04 & 0.0033 & 0.0025 & 321.58 & $\varnothing 8-156.23$ & $\varnothing 8-100$ \\
mty & 0.0763 & 0.4064 & 52.48 & 0.0026 & 0.0025 & 229.77 & $\varnothing 8-218.65$ & $\varnothing 8-100$ \\
mtix & 0.0354 & 0.1886 & 20.46 & 0.0010 & 0.0025 & 240 & $\varnothing 8-209.33$ & $\varnothing 8-200$ \\
mtiy & 0.0097 & 0.0514 & 6.64 & 0.0003 & 0.0025 & 220 & $\varnothing 8-228.36$ & $\varnothing 8-200$ \\
\hline \multicolumn{7}{c}{ Hasil analisis tulangan akhir pada kasus 11, 12 skema IVa } \\
\hline mlx & 0.0702 & 0.0648 & 7.03 & 0.0003 & 0.0025 & 240 & $\varnothing 8-209.33$ & $\varnothing 8-200$ \\
mly & 0.0277 & 0.0256 & 3.30 & 0.0002 & 0.0025 & 220 & $\varnothing 8-228.36$ & $\varnothing 8-200$ \\
mty & 0.1083 & 0.1000 & 12.91 & 0.0006 & 0.0025 & 220 & $\varnothing 8-228.36$ & $\varnothing 8-100$ \\
mtix & 0.0351 & 0.0324 & 3.52 & 0.0002 & 0.0025 & 240 & $\varnothing 8-209.33$ & $\varnothing 8-200$ \\
\hline
\end{tabular}

Tabel 3. Analisis Tulangan Pelat Lantai 3 dan 2 Kasus Pelat Dua Arah

\begin{tabular}{ccccccccc}
\hline $\mathrm{m}$ & koef & $\mathrm{Mu}$ & $\mathrm{Mu} / \mathrm{bd}^{2}$ & $\rho$ anl & $\rho$ min & $\begin{array}{c}\text { As } \\
\left(\mathrm{mm}^{2}\right)\end{array}$ & $\begin{array}{c}\text { Tulangan hasil } \\
\text { perhitungan }\end{array}$ & $\begin{array}{c}\text { Tulangan } \\
\text { terpasang }\end{array}$ \\
\hline \multicolumn{7}{c}{ Hasil analisis tulangan akhir pada kasus $1,2,3,4,6,8$ dan9 skema II } \\
\hline $\mathrm{mlx}$ & 0.053 & 0.2823 & 30.63 & 0.0015 & 0.0025 & 240 & $\varnothing 8-209.33$ & $\varnothing 8-200$ \\
$\mathrm{mly}$ & 0.015 & 0.0799 & 10.32 & 0.0005 & 0.0025 & 220 & $\varnothing 8-228.36$ & $\varnothing 8-200$ \\
$\mathrm{mtx}$ & 0.081 & 0.4314 & 46.81 & 0.0023 & 0.0025 & 240 & $\varnothing 8-209.33$ & $\varnothing 8-100$ \\
$\mathrm{mty}$ & 0.054 & 0.2876 & 37.14 & 0.0018 & 0.0025 & 220 & $\varnothing 8-228.36$ & $\varnothing 8-100$ \\
\hline \multicolumn{7}{c}{ Hasil analisis tulangan akhir pada kasus 5 dan7 skema VIIb } \\
\hline mlx & 0.0470 & 0.3870 & 41.99 & 0.0021 & 0.0025 & 240 & $\varnothing 8-209.33$ & $\varnothing 8-200$ \\
mly & 0.0185 & 0.1523 & 19.67 & 0.0010 & 0.0025 & 220 & $\varnothing 8-228.36$ & $\varnothing 8-200$ \\
$\mathrm{mtx}$ & 0.0780 & 0.6422 & 69.68 & 0.0035 & 0.0025 & 334.49 & $\varnothing 8-150.20$ & $\varnothing 8-100$ \\
$\mathrm{mty}$ & 0.0545 & 0.4487 & 57.94 & 0.0029 & 0.0025 & 254.09 & $\varnothing 8-197.72$ & $\varnothing 8-100$ \\
$\mathrm{mtiy}$ & 0.0093 & 0.0762 & 9.83 & 0.0005 & 0.0025 & 220 & $\varnothing 8-228.36$ & $\varnothing 8-200$ \\
\hline \multicolumn{7}{c}{ Hasil analisis tulangan akhir pada kasus 10 dan 11 skema III } & \\
\hline mlx & 0.067 & 0.3569 & 38.72 & 0.0019 & 0.0025 & 240 & $\varnothing 8-209.33$ & $\varnothing 8-200$ \\
mly & 0.020 & 0.1065 & 13.76 & 0.0007 & 0.0025 & 220 & $\varnothing 8-228.36$ & $\varnothing 8-200$ \\
mtx & 0.113 & 0.6019 & 65.31 & 0.0033 & 0.0025 & 321.58 & $\varnothing 8-156.23$ & $\varnothing 8-100$ \\
mty & 0.077 & 0.4101 & 52.96 & 0.0026 & 0.0025 & 229.77 & $\varnothing 8-218.65$ & $\varnothing 8-100$ \\
mtix & 0.0335 & 0.1784 & 19.36 & 0.0010 & 0.0025 & 240 & $\varnothing 8-209.33$ & $\varnothing 8-200$ \\
mtiy & 0.010 & 0.0533 & 6.88 & 0.0003 & 0.0025 & 220 & $\varnothing 8-228.36$ & $\varnothing 8-200$ \\
\hline \multicolumn{7}{c}{ Hasil analisis tulangan akhir pada kasus 12, 13 dan14 skema IVb } & \\
\hline mlx & 0.054 & 0.2876 & 31.21 & 0.0015 & 0.0025 & 240 & $\varnothing 8-209.33$ & $\varnothing 8-200$ \\
\hline
\end{tabular}




\begin{tabular}{ccccccccc}
\hline mly & 0.017 & 0.0906 & 11.69 & 0.0006 & 0.0025 & 220 & $\varnothing 8-228.36$ & $\varnothing 8-200$ \\
mtx & 0.082 & 0.4368 & 47.39 & 0.0024 & 0.0025 & 240 & $\varnothing 8-209.33$ & $\varnothing 8-100$ \\
mty & 0.053 & 0.2823 & 36.45 & 0.0018 & 0.0025 & 220 & $\varnothing 8-228.36$ & $\varnothing 8-100$ \\
mtiy & 0.0085 & 0.0453 & 5.85 & 0.0003 & 0.0025 & 220 & $\varnothing 8-228.36$ & $\varnothing 8-200$ \\
\hline \multicolumn{7}{c}{ Hasil analisis tulangan akhir pada kasus 15 skema Va } \\
\hline mlx & 0.0775 & 0.1153 & 12.51 & 0.0006 & 0.0025 & 240 & $\varnothing 8-209.33$ & $\varnothing 8-200$ \\
mly & 0.0281 & 0.0418 & 5.40 & 0.0003 & 0.0025 & 220 & $\varnothing 8-228.36$ & $\varnothing 8-200$ \\
mty & 0.1123 & 0.1670 & 21.57 & 0.0011 & 0.0025 & 220 & $\varnothing 8-228.36$ & $\varnothing 8-100$ \\
mtix & 0.0388 & 0.0576 & 6.25 & 0.0003 & 0.0025 & 240 & $\varnothing 8-209.33$ & $\varnothing 8-200$ \\
mtiy & 0.0141 & 0.0209 & 2.70 & 0.0001 & 0.0025 & 220 & $\varnothing 8-228.36$ & $\varnothing 8-200$ \\
\hline
\end{tabular}

Tabel 4. Hasil analisis tulangan akhir pada kasus pelat satu arah

\begin{tabular}{cccccccc}
\hline \multicolumn{7}{c}{ Hasil analisis tulangan akhir pada kasus pelat satu arah } \\
\hline $\begin{array}{c}\text { Tumpuan } \\
\text { dan lapangan } \\
1 / 8 W u(l x)^{2}\end{array}$ & 0.0315 & 4.07 & 0.0002 & 0.0025 & 220 & $\varnothing 8-228.36$ & $\varnothing 8-220$ \\
\hline
\end{tabular}

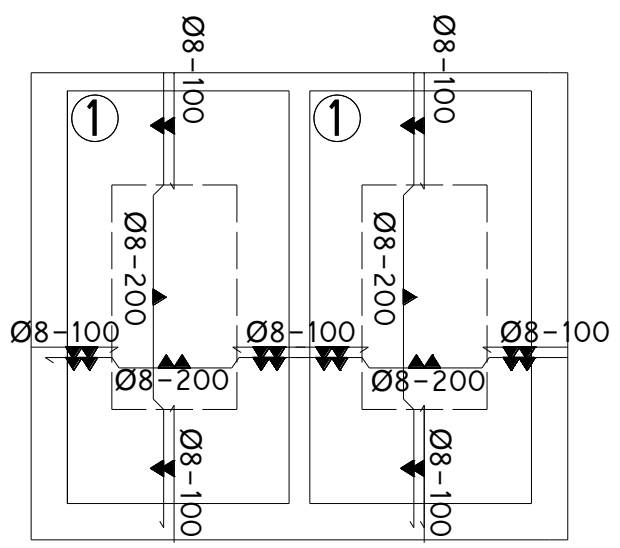

Gambar 5. Tulangan untuk kasus 1

\section{Kesimpulan Dan saran}

\subsection{Kesimpulan}

Dari hasil perhitungan dimensi dan tulangan pelat pada Ruko R1- Gabung No. 18, 20, 26, 28, 30, 32, 36 Bangunan Citraland Bagya City Medan diperoleh data- data sebagai berikut:

1. Dimensi/ tebal pelat lantai pada Ruko R1- Gabung No. 18, 20, 26, 28, 30, 32, 36 Bangunan Citraland Bagya City Medan telah sesuai dengan syarat SNI. Adapun tebal pelat yang digunakan adalah:

Pelat lantai atap $=100 \mathrm{~mm}$

Pelat lantai 4,3 dan $2=120 \mathrm{~mm}$

2. Tulangan yang digunakan pada Ruko R1- Bangunan Citraland Bagya City
Medan berdasarkan perhitungan tulangan terpasang adalah:

- Pada ruko no. 18 dan 36 lantai 2,3 dan 4, digunakan tulangan lapangan $\varnothing 8-200 \mathrm{~mm}$ dan tulangan tumpuan $\varnothing 8-100 \mathrm{~mm}$. Lantai atap digunakan tulangan lapangan $\varnothing 8-125 \mathrm{~mm}$ dan tulangan tumpuan $\varnothing 8$ - $250 \mathrm{~mm}$.

- Pada ruko no. 20, 26, 28, 30 dan 32 lantai 2,3 dan 4, digunakan tulangan lapangan $\varnothing 8-200 \mathrm{~mm}$ dan tulangan tumpuan $\varnothing 8-100$ $\mathrm{mm}$. Lantai atap digunakan tulangan lapangan $\varnothing 8-150 \mathrm{~mm}$ dan tulangan $\emptyset 8$ - $75 \mathrm{~mm}$ dan $\emptyset 8$ $225 \mathrm{~mm}$.

3. Pada penggambaran tulangan digunakan tabel hasil perhitungan sebagai pedoman penggambaran. Pada gambar dijelaskan tulangan pada tumpuan dan lapangan sesuai dengan hasil perhitungan.

\subsection{Saran}

Setelah melihat hasil analisa pembahasan dan kesimpulan maka saran penulis adalah untuk mendapatkan hasil perhitungan yang akurat, sebaiknya menggunakan software perhitungan seperti program Microsoft Excel. Karena selain perhitungan yang dihasilkan lebih akurat, program ini juga lebih cepat dan menghemat waktu dibandingkan alat hitung manual lainnya. Tentu saja 
ketelitian dalam penggunaan program ini sangatlah penting pada dasarnya.

\section{Daftar Pustaka}

Departemen Pekerjaan Umum. 1972. Pengendalian dan pelaksanaan Konstruksi. Jakarta: Badan Penerbit Pekerjaan Umum.

Departemen Pekerjaan Umum. 1987. Peraturan Muatan Indonesia (PMI). Jakarta: Badan Penerbit Pekerjaan Umum.

Dipohusodo, Istimawan. 1996. Struktur Beton Bertulang. Jakarta: Gramedia Utama.

Direktorat Penyelidikan Masalah Bangunan. 1971. Peraturan Beton Bertulang Indonesia (PBI). Jakarta: Direktorat Penyelidikan Masalah Bangunan.

Gideon, Kusuma. 1993. Dasar- dasar Perencanaan Beton Bertulang. Jakarta: Erlangga.

McCormac, Jack. 2002. Desain Beton BertulangEdisi kelima Jilid 2. Jakarta: Erlangga.

Mosley, W.H dan J.H Bungey. 1989. Perencanaan Beton Bertulang. Jakarta: Erlangga.

Schodek, L. Daniel. 1991. Struktur. Bandung: Refika Aditama.

Winter, Georgia dan Arthur H. Nilson. 1993. Perencanaan Struktur Beton Bertulang. Bandung: Pradnya Paramita.

PPI 1983 Pasal 3.1 dan 3.2. Peraturan Pembebanan Gedung.

SK SNI T-15-1991-03. Tata Cara Perhitungan Struktur Beton Bertulang.

SNI 03-1727-1989. Tata Cara Pembebanan Rumah dan Gedung.

SNI 03-2847-2002. Tata Cara Perencanaan Beton untuk Bangunan Gedung. 